\title{
Probabilistic seismic hazard assessment of Himachal Pradesh and adjoining regions
}

\author{
Nilesh Shaligram Patil, Josodhir Das, Ashwani Kumar, \\ Madan Mohan Rout and Ranjit Das* \\ Department of Earthquake Engineering, Indian Institute of Technology Roorkee, Roorkee 247 667, India. \\ ${ }^{*}$ Corresponding author.e-mail: ranjit244614@gmail.com
}

Seismically active Himachal Pradesh and adjoining regions comprising Himalayan orogenic belt with the experience of the great Kangra earthquake of 1905, has high potential for river valley projects. There are already operating hydropower projects, some under construction and a few more coming up. In view of this it is important to know the ground motion nature for various locales. The present study is about estimation of Peak Ground Acceleration (PGA) for the state of Himachal Pradesh and adjoining regions using probabilistic seismic hazard analysis (PSHA) approach. Standard procedure for PSHA has been adopted for this study and peak ground motion has been estimated for $10 \%$ and $2 \%$ probability of exceedance in 50 years at the bed rock level considering two cases: (i) varying $b$-value for each source zone, (ii) constant $b$-value for each source zone. For $10 \%$ probability of exceedance in 50 years, the PGA values vary from 0.096 to $0.15 \mathrm{~g}$ and 0.09 to $0.26 \mathrm{~g}$ considering varying $b$-value, and constant $b$-value, respectively. In case of $2 \%$ probability of exceedance in 50 years, the PGA varies between 0.07 to $0.24 \mathrm{~g}$ considering varying $b$-values and 0.14 to $0.37 \mathrm{~g}$ considering constant $b$-values. Higher PGA values are observed in the southeast part considering varying $b$-values whereas the region situated around Kaurik Fault System (KFS) has shown higher PGA values in case of constant $b$-value.

\section{Introduction}

Himachal Pradesh, a small state of India constituting Himalayan orogenic belt, is located in the north of the country, has experienced several moderate to large-sized earthquakes including the great Kangra earthquake of $1905\left(\mathrm{M}_{\mathrm{s}}=8.6, \mathrm{M}_{\mathrm{w}}=7.8\right)$. A major part of the region encompassing the state lies in Zones IV and V of the seismic zoning map of India (BIS-1893:2000 Part 1). The interplate/intraplate seismicity of the region is due to the continued convergence of the Indian plate against the Eurasian plate. This convergence has resulted in the formation of two major boundary thrusts, viz., the Main Central Thrust (MCT) and the Main Boundary Thrust (MBT), along almost the entire length of the Himalaya besides several other thrusts, faults and lineaments. The great Kangra earthquake of 4th April 1905, one of the most devastating earthquakes of the last century in northern India, took a toll of about 20,000 lives and caused massive destruction of buildings over a large area in the epicentral tract from Kangra to Mandi and in the region around Dehradun including the foothills of the Himalaya (Middlemiss 1909). The maximum observed intensity at the epicenter was nearly $\mathrm{X}$ on both Rossi-Forel and Medvedev-Sponheuer-Karnik scales. The epicenter of the Kangra earthquake could not be estimated instrumentally due to lack of data. However, based on the pattern of damage and observed intensity in and around KangraDharamshala region epicentre could be fixed at

Keywords. Himachal Pradesh; seismicity, PSHA; seismogenic source zones; PGA. 
around latitude $32^{\circ} 5^{\prime} \mathrm{N}$ and longitude $76^{\circ} 5^{\prime} \mathrm{E}$. The focal depth of Kangra earthquake seems to be shallow; less than $20 \mathrm{~km}$ and estimated length of fault rupture is about $100-150 \mathrm{~km}$ based on intensity distribution (Quittmeyer and Jacob 1979; Chander 1988). The aftershocks of the Kangra earthquake were spread over a large area and continued for many years (Srivastava et al. 2010). In spite of the intense seismic activities of the region, several hydropower projects are coming up to harness the water resources available and convenience to locate dams. To establish such important projects it becomes very necessary to know the expected ground motion at various locales. In view of this, Probabilistic Seismic Hazard Analysis (PSHA) of the region in and around the state of Himachal Pradesh has been performed to estimate PGA. A large area bounded by latitudes $27.5^{\circ}$ to $36.0^{\circ}$ and longitudes $73.5^{\circ}$ to $83.5^{\circ}$ has been considered to include influencing tectonic features and geotectonic domains for PSHA. For the purpose of digitization of tectonic features, plotting earthquakes magnitude-wise, creation of seismogenic source zones, earthquake extraction for each zone, area estimation, zone boundary co-ordinates, the software ArcGIS 10.0 has been employed. PSHA is important as occurrence of earthquakes in the mountainous region leads to a number of associated disasters such as landslides, damming of rivers and various types of slope failures. The information from PSHA shall be helpful to devise an appropriate mechanism to mitigate disastrous effects of earthquakes.

\section{Tectonics and seismicity of the region}

The knowledge about the tectonics and seismicity of the region is used to identify and demarcate seismogenic source zones and its seismic characteristics, zone area formed as major input for PSHA. From the geological and tectonic stand point, the state of Himachal Pradesh and surrounding regions comprise of two distinct geotectonic domains namely, the Himalayan orogenic belt and the Indo-Gangetic Plains. Major geotectonic units and seismogenic features present in the study area belong to the Himalayan orogenic belt. Several subsurface tectonic features (e.g., Mahendragarh-Dehradun Fault (MDF)) occur at depth in the Indo-Gangetic Plains. Rock sequences exposed range from Quaternary alluvial deposits of the Indo-Gangetic Plains occurring in the southwestern part to Proterozoic age. The litho-tectonic units of the Himalayan orogenic belt primarily consist of poorly metamorphosed litho-units of the Tethyan sequence, high and low grade metamorphic rocks in the Higher and Lesser Himalaya, and frontal belt of sedimentary rocks (Shiwalik formations) of the sub-Himalaya. Further to the southwest of the sub-Himalaya are the Indo-Gangetic Plains represented by the alluvial fill of the Quaternary deposits along the Ganga foredeep.

The state of Himachal Pradesh and the surrounding region, forming part of the western Himalaya, lie on seismically active Alpide belt which passes through the Himalaya. The high level of natural seismicity of the region is attributed to the collision and subsequent under thrusting of the India plate beneath the Eurasia Plate. The process of collision and under thrusting led to the formation of two northerly dipping intra-continental thrusts namely, the MCT and the MBT south of the plate boundary. The MBT is a series of thrusts that separates the Lesser Himalaya from the sub-Himalaya. In the Garhwal and the Kumaon Himalaya, different segments of the MBT are recognised by their regional names such as Riasi, Nahan and Krol thrusts (Valdiya 1980). The northeastward dipping MCT demarcates the boundary between the Higher Himalaya and the Lesser Himalaya and separates the central crystalline zone from the low grade metamorphic rocks of the Lesser Himalaya (Gansser 1977). MCT, the most conspicuous structural element of the Himalaya, terminates against Kishtwar Fault (KF) in Jammu and Kashmir. The region falling towards northeast of the state is dissected by three prominent tectonic features, viz., Bangong-Nujiang Suture (BNS), Indus Suture Zone (ISZ) and Karakoram Fault (KKF). The BNS is represented by melange containing fragments of ophiolites which were thrust from north to south in late Jurrassic Era. The ISZ marks the boundary between the India and the Tibet plates. The KKF, one of the most prominent tectonic features present in the region, extends for almost $1000 \mathrm{~km}$ from Central Pamir to Kumaon Himalaya. This fault has affected the region with a huge dextral offset and is traceable towards northwest through the Shyok suture to the Pamir. Sundernagar Fault (SNF), an important transverse fault in the Western Himalaya, exhibits a dextral structure extending from Higher Himalaya to Frontal Belt. This fault is also called the Manali Fault, which is considered to have caused the swing of the Frontal Belt from NW-SE to N-S. The region falling to the east of the $\mathrm{SNF}$, is marked by the presence of Kaurik Fault System (KFS). The KFS of Higher Himalaya is an important transverse feature, characterised by normal faulting and exhibits splays that might have ruptured during the Kinnaur earthquake of 1975 (GSI 2000).

The Almora Thrust defines the tectonic base of the great Almora Napee (Valdiya 1980) which is a synclinal thrust sheet, flanked by the very low northerly dipping South Almora Thrust and 


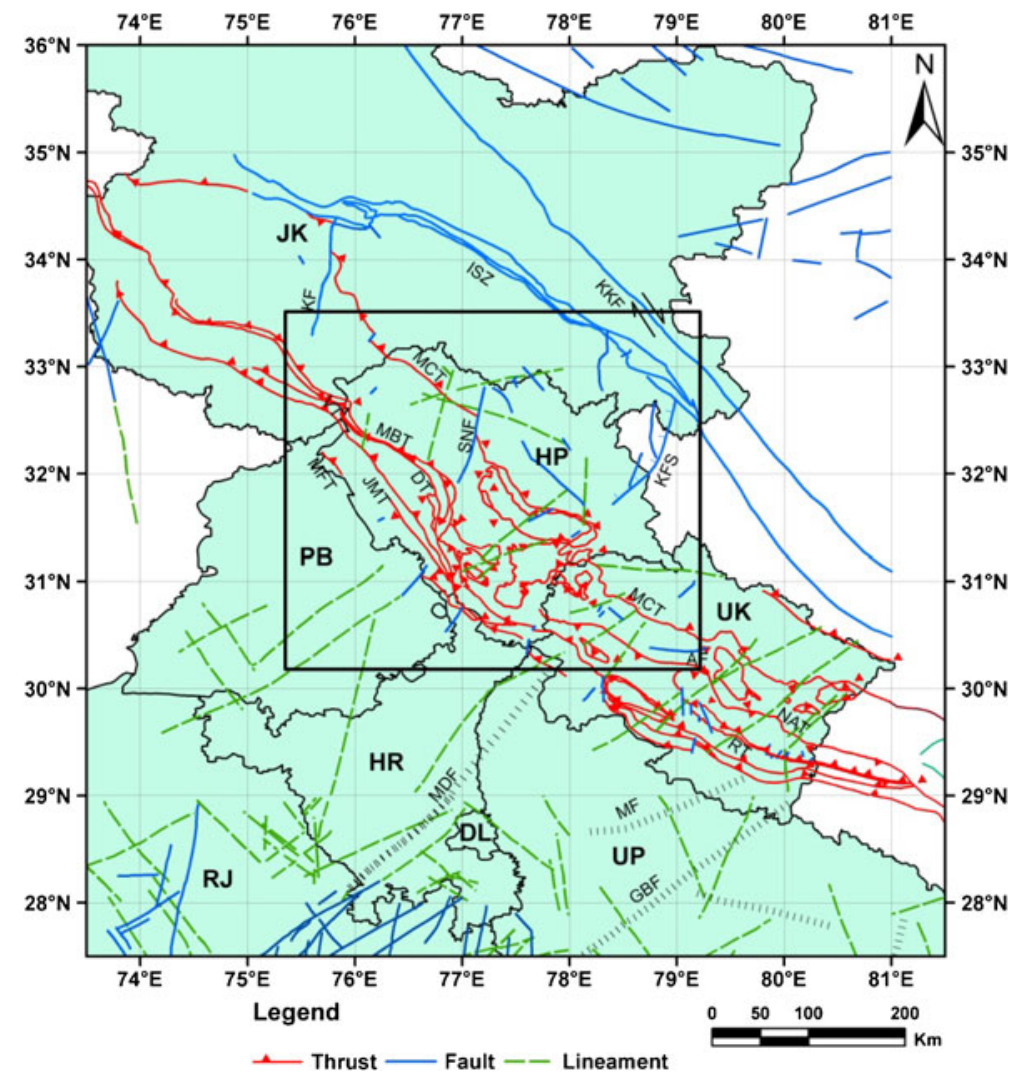

Figure 1. Tectonic features present in and around Himachal Pradesh, HP: Himachal Pradesh, UK: Uttarakhand, UP: Uttar Pradesh, DL: Delhi, RJ: Rajasthan, HR: Haryana, PB: Punjab, JK: Jammu and Kashmir. MCT: Main Central Thrust, MBT: Main Boundary Thrust, SNF: SunderNagar Fault, KKF: Karakoram Fault, ISZ: Indus Suture Zone, KF: Kishtwar Fault, KFS: Kaurik Fault System, SS: Shyok Suture, JF: Jhelum Fault, JMT: JwalaMukhi Thrust, MDF: MahendragarhDehradun Fault, MF: Moradabad Fault, DT: Drang Thrust, NAT: North Almora Thrust, RT: Ramgarh Thrust, GBF: Great Boundary Fault, AF: Alaknanda Fault. Box shows the area for which PSHA is carried out. (Tectonic features are taken from Seismotectonic Atlas of India and its environs by GSI 2000)

southerly dipping North Almora Thrust. The EW trending Alaknanda Fault (AF), another conspicuous tectonic feature extends for a considerable distance. This fault delimits a number of lithotectonic units of Chamoli Schuppen Zone. In the Ganga foredeep several major subsurface faults, viz., the Moradabad Fault (MF) and the Great Boundary Fault (GBF), oriented transversely to the Himalayan arc have been recognised. Figure 1 shows the tectonic features of the region which includes thrusts, faults and various lineaments present.

The seismicity of the region is closely associated with the mapped regional tectonic features thrusts/ faults. The region has experienced several earthquakes of moderate-to-large magnitudes in the last two centuries. Notable among these are: the Kangra earthquake of $1905\left(\mathrm{M}_{\mathrm{w}}=7.8\right)$, the Chamba earthquake of $1945\left(m_{b}=6.5\right)$, the Kinnaur earthquake of $1975 \quad\left(m_{b}=6.5\right)$, the Dharamshala earthquake of $1986\left(m_{b}=5.5\right)$, the Uttarkashi earthquake of $1991\left(m_{b}=6.4\right)$, the Chamoli earthquake of $1999\left(m_{b}=6.8\right)$ and the Kashmir earthquake of $2005\left(\mathrm{M}_{\mathrm{w}}=7.6\right)$. Most of the earthquakes in this region occur at shallow depths less than $20 \mathrm{~km}$.

\section{Demarcation of seismogenic source zones}

For the purpose of PSHA of the state of Himachal Pradesh (HP), a large region around HP bounded by latitude $27.5^{\circ}$ to $36.0^{\circ}$ and longitude $73.5^{\circ}$ to $81.5^{\circ}$ has been considered and divided into several seismogenic source zones. Based on geologic evolution, tectonic framework and seismicity, the region has been divided into ten seismogenic source zones. The delineated seismogenic source zones along with seismicity and tectonic features are shown in figure 2. The seismogenic source zones I, II and III cover the state of HP where seismic hazard were to be estimated. The seismogenic source zone I encompass the Kangra-Chamba region and include the epicentral tract of the great Kangra earthquake. Segments of the MBT and the MCT also traverse through the region. Two transverse features, viz., the SNF and the KF also fall in this 


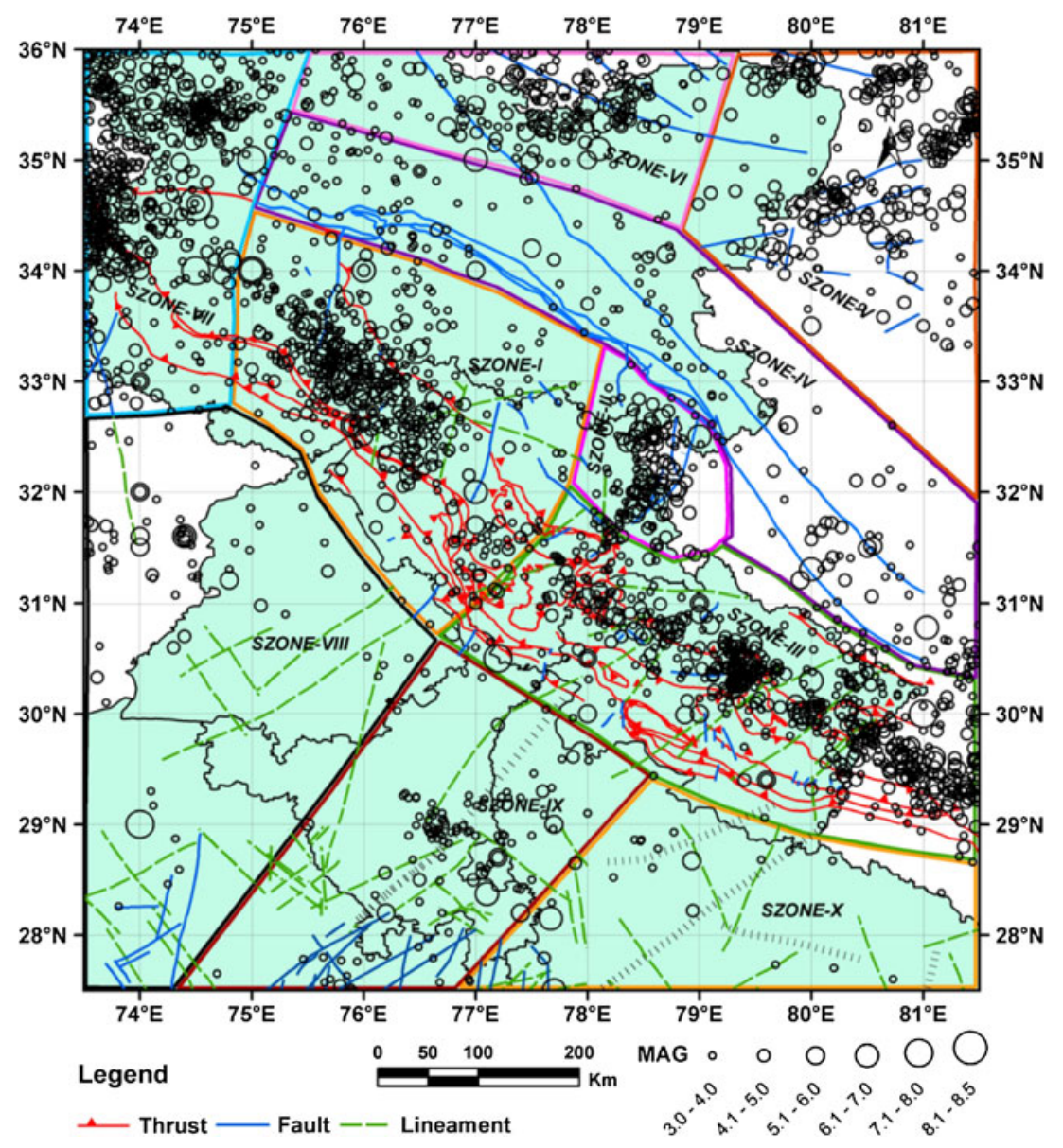

Figure 2. Demarcation of seismogenic source zones based on geology, tectonics and seismicity.

Table 1. Important characteristic of the seismogenic source zones.

\begin{tabular}{|c|c|c|c|c|c|c|c|c|}
\hline \multirow{2}{*}{$\begin{array}{l}\text { Source } \\
\text { zone }\end{array}$} & \multirow{2}{*}{$\begin{array}{c}\text { Area } \\
\left(\mathrm{km}^{2}\right)\end{array}$} & \multirow[b]{2}{*}{ Total EQ } & \multicolumn{4}{|c|}{ Seismicity of the region $\left(\mathrm{M}_{\mathrm{w}}\right)$} & \multirow{2}{*}{$\begin{array}{l}\text { Important } \\
\text { earthquake }\end{array}$} & \multirow{2}{*}{$\begin{array}{l}\text { Important } \\
\text { magnitude }\end{array}$} \\
\hline & & & $\leq 4.9$ & $5.0-6.9$ & $7.0-7.9$ & $\geq 8.0$ & & \\
\hline I & 92684.7 & 479 & 438 & 32 & 8 & 1 & 1905 April 4 & 8.0 \\
\hline II & 20865.7 & 115 & 95 & 20 & 0 & 0 & 1975 January 19 & 6.8 \\
\hline III & 101931.0 & 606 & 517 & 85 & 3 & 1 & 260 A.D. & $8.0(\mathrm{NA})$ \\
\hline IV & 115736.0 & 178 & 165 & 12 & 1 & 0 & 1701 January 1 & 7.0 \\
\hline V & 86093.1 & 262 & 220 & 41 & 1 & 0 & 2008 March 20 & 7.2 \\
\hline VI & 47274.8 & 207 & 184 & 23 & 0 & 0 & 1996 November 19 & 6.9 \\
\hline VII & 59855.2 & 542 & 491 & 45 & 4 & 2 & 1555 February 1 & $8.5(\mathrm{NA})$ \\
\hline VIII & 133948.4 & 69 & 57 & 11 & 1 & 0 & 1905 September 26 & 7.1 \\
\hline IX & 82554.4 & 114 & 103 & 11 & 0 & 0 & 1720 July 15 & 6.5 \\
\hline $\mathrm{X}$ & 69935.1 & 21 & 19 & 2 & 0 & 0 & 1956 October 10 & 6.7 \\
\hline
\end{tabular}

(NA = Not assigned.)

source zone. The seismogenic source zone II has been delineated keeping in view the high level of seismicity associated with KFS. Tectonic motion along KFS has caused the Kinnaur earthquake of 1975.

Seismogenic source zone III covers part of HP state and almost entire Uttarakhand state. This source zone includes the segments of the MBT and the MCT that run parallel to Himalayan arc. The Alaknanda Fault, the North Almora Thrust and the South Almora Thrust are also present in this zone. Seismogenic source zone IV covers segments of the ISZ and KKF and runs almost parallel to these major geotectonic features. Seismogenic source zone $\mathrm{V}$ is located to the northeast of the state of HP and includes part of Tibet. 
The segment of BNS falls in this source zone along with several other faults of local scale. Seismogenic source zone VI is located to north and includes the segments of BNS and KKF. Seismogenic source zone VII is one of the most seismically active sources and mostly covers regions of the Jammu and Kashmir state. Terminated segment of the MCT along with some local faults are included in this zone. Seismogenic source zones VIII, IX and X fall in the Indo-Gangetic Plains and are comparatively less active as compared to other seismogenic source zones falling in the Himalayan orogenic belt. These source zones contain sub-surface faults, viz., MDF, MF and GBF affecting the basement.

Some of the lineaments and faults are trending almost orthogonal to the Himalayan orogenic belt. Some of the important characteristics of the delineated seismogenic source zones are listed in table 1.

\section{Methodology adopted for PSHA}

Methodology adopted for PSHA is fairly well known (Reiter 1990) and involves estimating magnitude-dependant characteristics of the seismicity rate for each seismogenic source zone adopting Gutenberg-Richter relationship (1944) which is expressed as: $\log \lambda_{m}=a-b m$, where, $\lambda_{m}$ is the mean annual rate of exceedance of earthquakes having magnitude greater than or equal to $m, 10^{\mathrm{a}}$ is the mean yearly number of earthquakes of magnitude greater than or equal to zero (Kramer 2003). Parameter $b$ signifies the relative likelihood of large to small earthquakes and is normally computed for each seismogenic source zone. However in case the data is insufficient to estimate $b$-value, the $b$-value can be assumed constant for the whole region. In this study, PSHA has been carried out considering the $b$-value for each source zone and also assuming constant $b$-value for the entire region.

A homogeneous earthquake catalog is an important input for estimation of seismic hazard study. The earthquake catalog for the region has been compiled from three agencies: IMD catalog of seismic events from 1552-2011, ISC catalog of seismic events from 1720-1972, and USGS catalog of seismic events from 1973-2011. These three catalogs were combined and the repeated events were identified and removed on the basis of magnitude, occurrence time and location. In addition, some local catalogs prepared by Oldham (1883) and Iyengar et al. (1999) were also consulted. The preparation of a homogeneous earthquake catalog for a seismic region needs regressed relations for conversion of different magnitudes types, e.g., $m_{b}, \mathrm{M}_{\mathrm{s}}$, to the unified moment magnitude $\mathrm{M}_{\mathrm{w}}$. In case both the magnitudes have measurement errors, due to saturation or otherwise, the use of least-squares linear regression procedure may yield wrong results. In such a situation, it is appropriate to use General Orthogonal Regression (GOR) procedure which takes into account the errors on both the magnitudes (Joshi and Sharma 2008; Thingbaijam et al. 2008; Ristau 2009; Das et al. 2012a, 2013; Wason et al. 2012). As the derivation of GOR relation involves the orthogonal projection of observed magnitude data pairs on the GOR line, the computation of estimates of a preferred magnitude type using these GOR relations in their existing form is liable to introduce some error. As orthogonal residuals are used in the development of GOR relations, their usage for magnitude conversion also requires taking into account the orthogonal criteria (Wason et al. 2012). Appropriate global relations have been used given by Wason et al. (2012) and regional relations for conversion of body wave magnitude to moment magnitude (Das et al. 2013). In order to convert historical earthquakes with intensity values only, the empirical relation $\mathrm{M}_{\mathrm{w}}=0.762$ * MMI + 0.865 (Das et al. 2012b) has been used to estimate magnitude from intensity data. This exercise resulted in the preparation of the cata$\log$ for the study region which consists of 2708 earthquakes.

The next step consists of declustering the earthquake catalog, which involves removal of aftershocks and foreshocks. For this purpose, the earthquake catalog was analysed and dependant events were removed based on Gardner and Knopoff (1974) approach considering 100 days time window (Musson 1999). Declustering eliminated 29\% events from the catalog. The declustered cata$\log$ includes 1862 earthquakes with $\mathrm{M}_{\mathrm{w}} \geq 3.0$ for the study region. The incomplete earthquake data may lead to underestimation of the mean rate of earthquake occurrence. Hence, for reliable mean rate of earthquake occurrence for the given magnitude range, the analysis of completeness has been carried out by adopting the procedure given by Stepp (1972), which gave the extent to which all the reported earthquakes in a catalog for a given magnitude range and time period are complete.

Table 2. Completeness of magnitude in different classes with reporting period.

\begin{tabular}{lcc}
\hline $\begin{array}{l}\text { Magnitude } \\
\text { class }\left(\mathrm{M}_{\mathrm{w}}\right)\end{array}$ & $\begin{array}{c}\text { Completeness } \\
\text { period }\end{array}$ & $\begin{array}{c}\text { Reporting period } \\
\text { (years) }\end{array}$ \\
\hline $3.0-3.9$ & $1981-2011$ & 30 \\
$4.0-4.9$ & $1961-2011$ & 50 \\
$5.0-5.9$ & $1921-2011$ & 90 \\
$6.0-6.9$ & $1811-2011$ & 200 \\
$\geq 7.0$ & $1811-2011$ & 200 \\
\hline
\end{tabular}




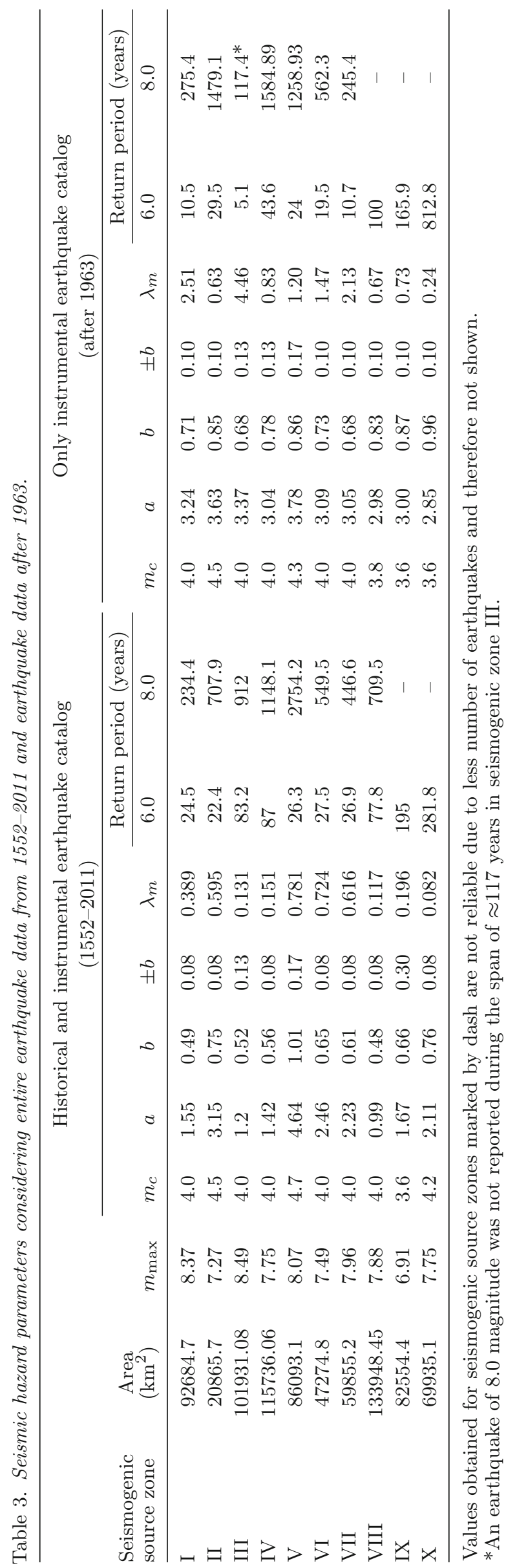


The completeness analysis has been performed by grouping the earthquakes in five magnitude classes: $3 \leq \mathrm{M}_{\mathrm{w}} \leq 3.9,4.0 \leq \mathrm{M}_{\mathrm{w}} \leq 4.9,5.0 \leq \mathrm{M}_{\mathrm{w}} \leq 5.9$, $6.0 \leq \mathrm{M}_{\mathrm{w}} \leq 6.9$ and $7.0 \leq \mathrm{M}_{\mathrm{w}}$ and the results are given in the table 2 .

\section{Estimation of seismic hazard parameters}

Recurrence relation has been computed for each seismogenic source zone to allow estimation of seismic hazard parameters. For this purpose, the earthquake catalog has been classed as: (i) considering the entire earthquake catalog for the period from 1552 to 2011, and (ii) considering earthquake catalog based on data for the period from 1963 to 2011. With the installation of WWSSN and other networks in 1960s, quality and quantity of seismological data greatly improved. The seismic hazard parameters are computed using Entire Magnitude Range Method (EMR) modified by Woessner and Wiemer (2005). This method is stable under most conditions and provides a comprehensive seismicity

Table 4. Maximum observed and expected magnitude with deviation.

\begin{tabular}{lcc}
\hline Zone & $\begin{array}{c}\text { Maximum observed } \\
\text { magnitude } \\
\left(m_{\max }^{\text {obs }}\right)\end{array}$ & $\begin{array}{c}\text { Maximum magnitude } \\
(\text { N-P-G estimator }) \\
\left(m_{\max }\right)\end{array}$ \\
\hline I & 8.0 & $8.37 \pm 0.30$ \\
II & 6.8 & $7.27 \pm 0.76$ \\
III & 8.0 & $8.49 \pm 0.52$ \\
IV & 7.0 & $7.75 \pm 0.86$ \\
V & 7.2 & $8.07 \pm 0.66$ \\
VI & 6.9 & $7.49 \pm 0.58$ \\
VII & 7.7 & $7.96 \pm 0.44$ \\
VIII & 7.1 & $7.88 \pm 0.76$ \\
IX & 6.5 & $6.91 \pm 0.45$ \\
X & 6.7 & $7.75 \pm 1.07$ \\
\hline
\end{tabular}

model. For seismogenic source zones VIII, IX and $\mathrm{X}$, EMR method did not work due to less number of earthquakes. Therefore, for these source zones Maximum Curvature method has been adopted although it has been reported that this method slightly underestimates the magnitude of completeness (Woessner and Wiemer 2005). In the present study, ZMAP (Wiemer and Wyss 2001) software has been used to compute seismic hazard parameters.

Estimates of seismic hazard parameters considering both types of catalogs are listed in table 3 . The seismic hazard parameters obtained from the catalog for the period from 1964 to 2011 are further used for hazard analysis because return period based on instrumental seismicity data was found to provide reliable results. Further, seismic hazard parameter $a$ represents the seismicity rate and its higher value shows higher seismicity of the region. In view of these considerations and observations the earthquake data after 1963 has been used to calculate $a$ and $b$-values for the estimation of seismic hazard.

The maximum magnitude $\left(m_{\max }\right)$ defines the upper limit of magnitude for a given seismogenic source zone. As $m_{\max }$ reflects maximum potential of strain release in the scenario earthquake, it plays a vital role in probabilistic seismic hazard assessment. In the present study the Non-Parametric Gaussian (N-P-G) based estimator equation given by Kijko (2004) has been used to compute $m_{\max }$ adopting Kijko's $\mathrm{M}_{\max }$ Toolbox written in MATLAB. The maximum observed magnitude $\left(m_{\max }^{\text {obs }}\right)$ and maximum magnitude $\left(m_{\max }\right)$ estimated adopting Kijko's approach are listed in table 4.

The probability of exceedance of earthquakes of different magnitudes in 100 years has been estimated for all seismogenic source zones and is depicted in figure 3 . The return period is an important parameter computed from the inverse of annual probability of exceedance. Considering the

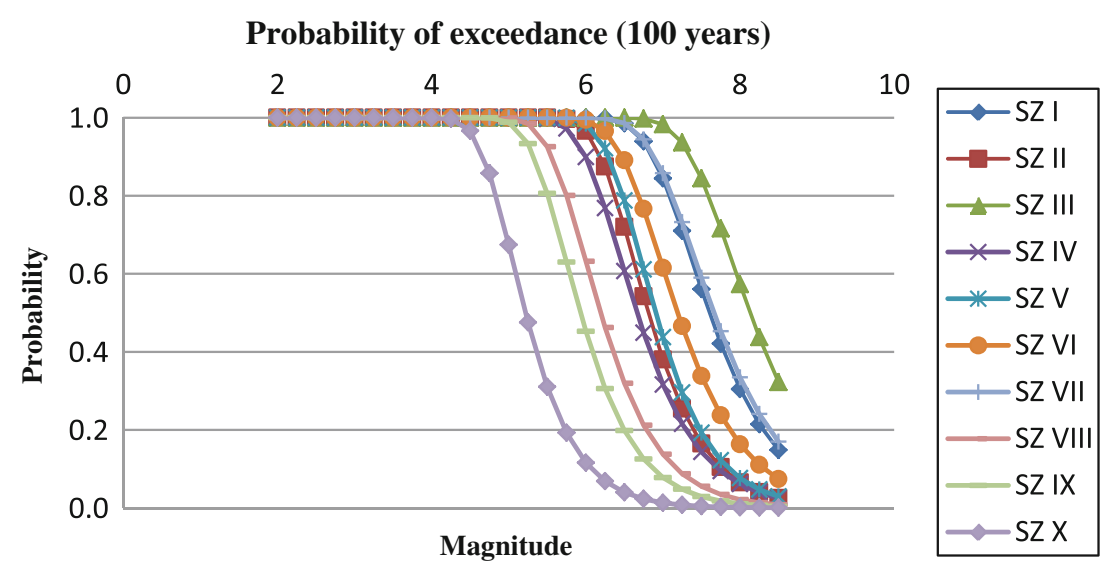

Figure 3. The probability of exceedance in 100 years. 


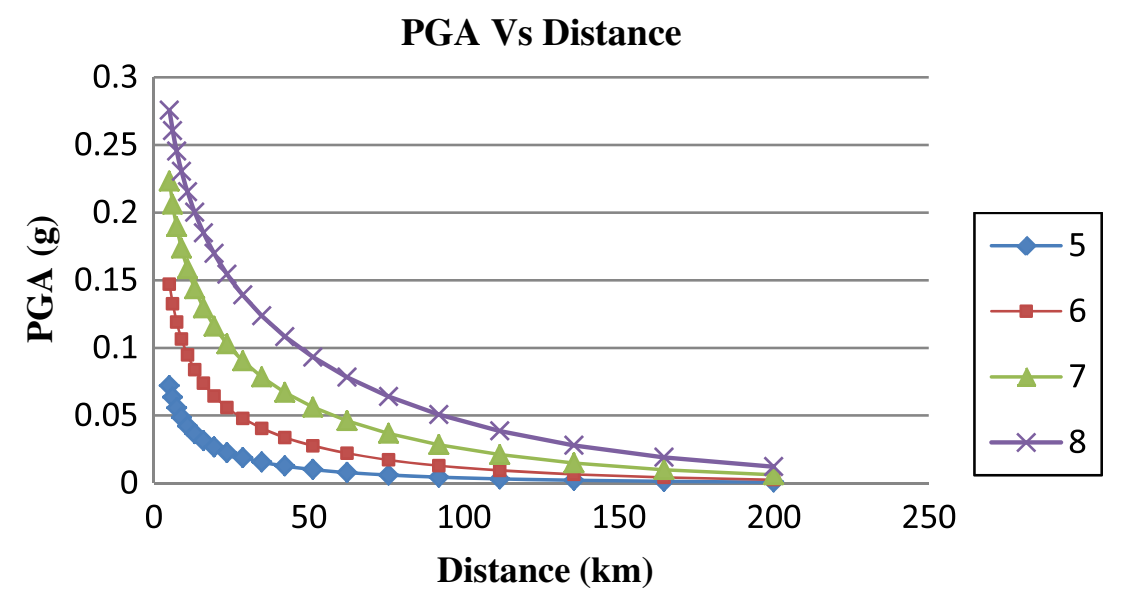

Figure 4. Prediction of PGA for different magnitudes with attenuation model of Boore and Atkinson (2008).

return period of earthquake with magnitude 6.0 , it is observed that source zones III, I and VII have low return periods around 5, 10 and 11 years, respectively whereas source zone $\mathrm{X}$ has highest return period of 812 years.

\section{Attenuation model}

An attenuation model for shallow crustal earthquakes proposed by Boore and Atkinson (2008) has been used to estimate Peak Ground Acceleration (PGA). This model has been developed considering a large database of thousands of worldwide strong-motion records, compiled by the Pacific Earthquake Engineering Research Centre, Next Generation Attenuation (PEER NGA) project, and an additional three datasets the details of which have been described by the authors. The Ground Motion Prediction Equation provides average horizontal component of ground motions as a function of earthquake magnitude, distance from source to site, local average shear wave velocity and fault type. This model gives PGA, PGV and $5 \%$ damped Pseudo-absolute acceleration spectra (PSA) at periods from 0.01 to $10 \mathrm{~s}$ and is applicable for magnitude range from 5 to $8, R_{J B}<200 \mathrm{~km}$ and $V_{S 30}=180$ to $1300 \mathrm{~m} / \mathrm{s}$ (Boore and Atkinson 2008). The general attenuation model is described by the following equation,

$$
\begin{aligned}
\ln Y= & F_{M}(M)+F_{D}\left(R_{J B}, M\right) \\
& +F_{S}\left(V_{S 30}, R_{J B}, M\right)+\varepsilon \sigma_{T} .
\end{aligned}
$$

In this equation $F_{M}, F_{D}$, and $F_{S}$ represent the magnitude scaling, distance function and site amplification, respectively. $M, R_{J B}$, and $V_{S 30}$ indicate the moment magnitude, closest distance to the surface projection of the rupture (Joyner-Boore distance in $\mathrm{km}$ ), and the shear-wave velocity in $\mathrm{m} / \mathrm{s}$ over the top $30 \mathrm{~m}$, respectively. The coefficient $\varepsilon$ is the fractional number of standard deviation of a single predicted value of $\ln Y$ from the mean value of $\ln Y$. All terms, including the co-efficient $\sigma_{T}$ are period dependent. $\sigma_{T}$ is computed using the equation:

$$
\sigma_{T}=\sqrt{\left(\sigma^{2}+\tau^{2}\right)}
$$

where $\sigma$ is the intra-event aleatory uncertainty and $\tau$ is the inter-event aleatory uncertainty. In the present work, shear wave velocity $\left(V_{S 30}\right)$ is taken as $1300 \mathrm{~m} / \mathrm{s}$ which means peak ground motion is computed at bed rock level. The predicted PGA at different magnitudes as a function of distance is shown in figure 4.

\section{Seismic hazard estimation}

The standard methodology developed by Cornell (1968) for PSHA is normally applied for the estimation of seismic hazard in terms of PGA for $10 \%$ and $2 \%$ probability of exceedance in 50 years. For the purpose of estimating ground motion at different points as close as possible, the study area has been divided into 320 small grids of size $0.2^{\circ} \times 0.2^{\circ}$. The probabilistic seismic hazard estimation software CRISIS-2007 developed by Ordaz et al. (2003) has been used. In the computational scheme, parameters such as $a, b, m_{c}, m_{\max }$ and attenuation models are the input parameters in the CRISIS programme and PGA and PSA are the output. For this study attenuation model of Boore and Atkinson (2008) has been adopted because they considered worldwide quality strong motion data for deriving the ground motion prediction equation for shallow crustal earthquakes. Using this attenuation model spectral ordinates (values) were calculated at important structural periods from 0.1 to $4 \mathrm{~s}$ for different magnitudes at different distances. The 


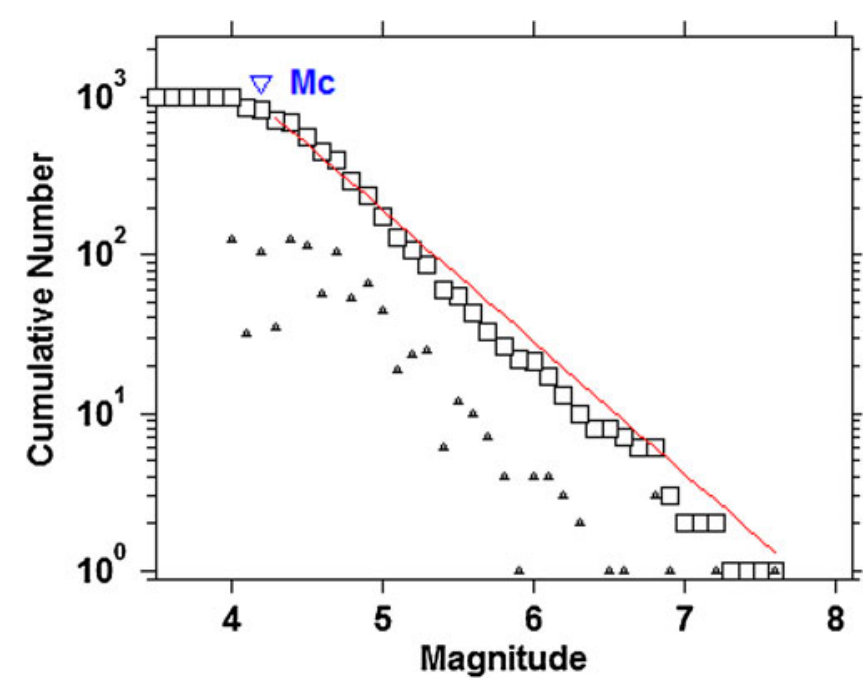

Figure 5. Frequency-magnitude relation for the region.

results obtained have been prepared in tabular format and used in CRISIS programme to introduce effects of user attenuation model. The estimated PGA has been presented in the form of zone maps for different return periods.

An attempt has also been made to estimate seismic hazard keeping constant $b$-value $(b=0.85)$ for all seismogenic source zones and same $a$ value as obtained from previous analysis for each seismogenic source zone. For this purpose, the whole region has been considered as a single large seismogenic source zone and considering all earthquake data within the region, seismic hazard parameters are computed by EMR method. Figure 5 shows frequency-magnitude relation for the entire region, and the estimated seismic hazard parameters are $b$-value $=0.84, a$-value $=4.84$, magnitude of completeness $=4.2$. Thus, in the present study, PGA zone maps, computed considering different $b$-value for each seismogenic source zone and constant $b$-value for the entire region is compared.

\section{Results and discussion}

For the purpose of estimating PSHA, the state of $\mathrm{HP}$ and surrounding area between latitude $30^{\circ} 2^{\prime}-$ $33^{\circ} 6^{\prime} \mathrm{N}$ and longitude $75^{\circ} 3^{\prime}-79^{\circ} 15^{\prime} \mathrm{E}$ is divided into 320 small grids of size $0.2^{\circ} \times 0.2^{\circ}$ (figure 6 ). PGA has been computed at the centre of all the grid points for return period of 475 years and 2500 years (i.e., $10 \%$ and $2 \%$ probability of exceedance in 50 years) and ground motion distribution is shown in the form of zones considering varying $b$-value for each seismogenic source zones (Case I) and constant $b$-value for the whole region (Case II).

Case I: For the return period of 475 years, the study has brought out that the south-eastern

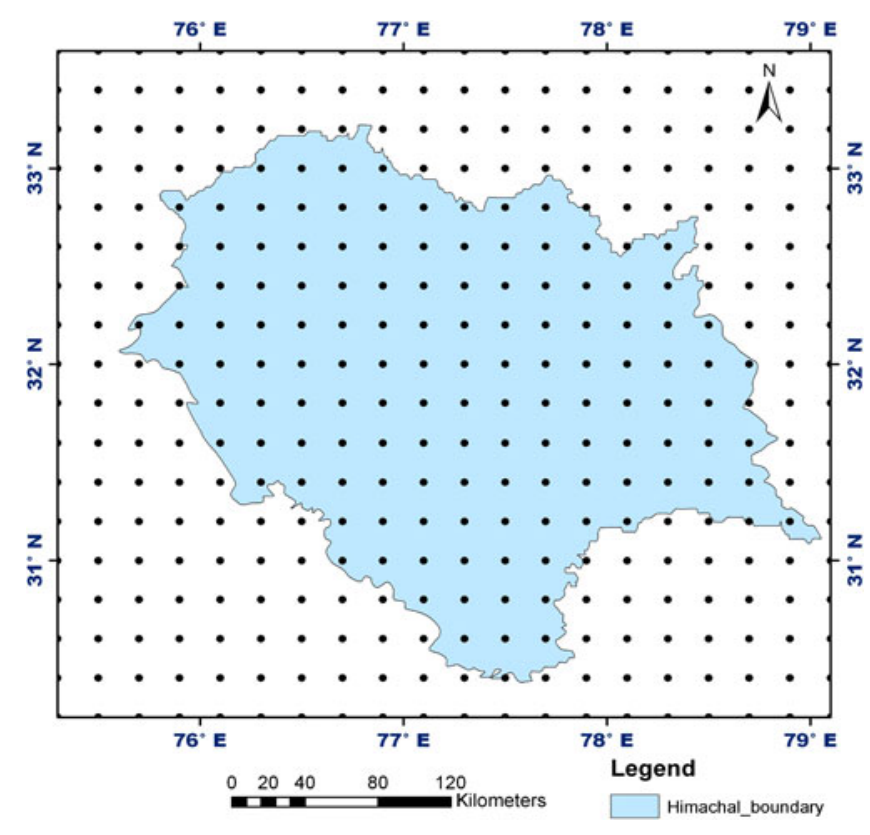

Figure 6. The state boundary of $\mathrm{HP}$ and adjoining regions divided by $0.2^{\circ} \times 0.2^{\circ}$ size grid.

part of the study area including the state capitals Shimla and Dehradun of HP and Uttarakhand respectively show higher hazard level (figure 7a). For major parts of the state of HP, PGA varies from 0.12 to $0.13 \mathrm{~g}$. However, small segments in the central part of the state have hazard level 0.09 to $0.11 \mathrm{~g}$. Areas located northeast and southwest, have less hazard level. In general, for the state of HP, the PGA varies from 0.09 to $0.15 \mathrm{~g}$ for 475 years return period. However, for return period of 2500 years, the PGA varies from 0.19 to $0.21 \mathrm{~g}$ in the major part of the state (figure $7 \mathrm{~b}$ ). As in the earlier case, in the south-eastern part of the study area PGA varies from 0.22 to $0.24 \mathrm{~g}$.

Case II: Considering constant $b$-value for whole region, it has been found that PGA varies from 0.09 to $0.26 \mathrm{~g}$ in major parts of the state for 475 years return period (figure 8a). However, the region around KFS in the eastern part of the state has higher hazard level with maximum expected PGA in the range from 0.24 to $0.26 \mathrm{~g}$. Further, the regions north of Keylong and near Chamba also have higher hazard level as compared to central part of the state with expected PGA ranges between 0.21 and $0.23 \mathrm{~g}$. Whereas, for return period of 2500 years, the regions situated to the north and east of the state show highest hazard level with expected PGA varying from 0.34 to $0.37 \mathrm{~g}$ in the region around KFS (figure $8 \mathrm{~b}$ ). The expected PGA fall in the range from 0.27 to $0.30 \mathrm{~g}$ in the regions straddling the state boundary towards north and southeast of the state including the state capital Shimla. 


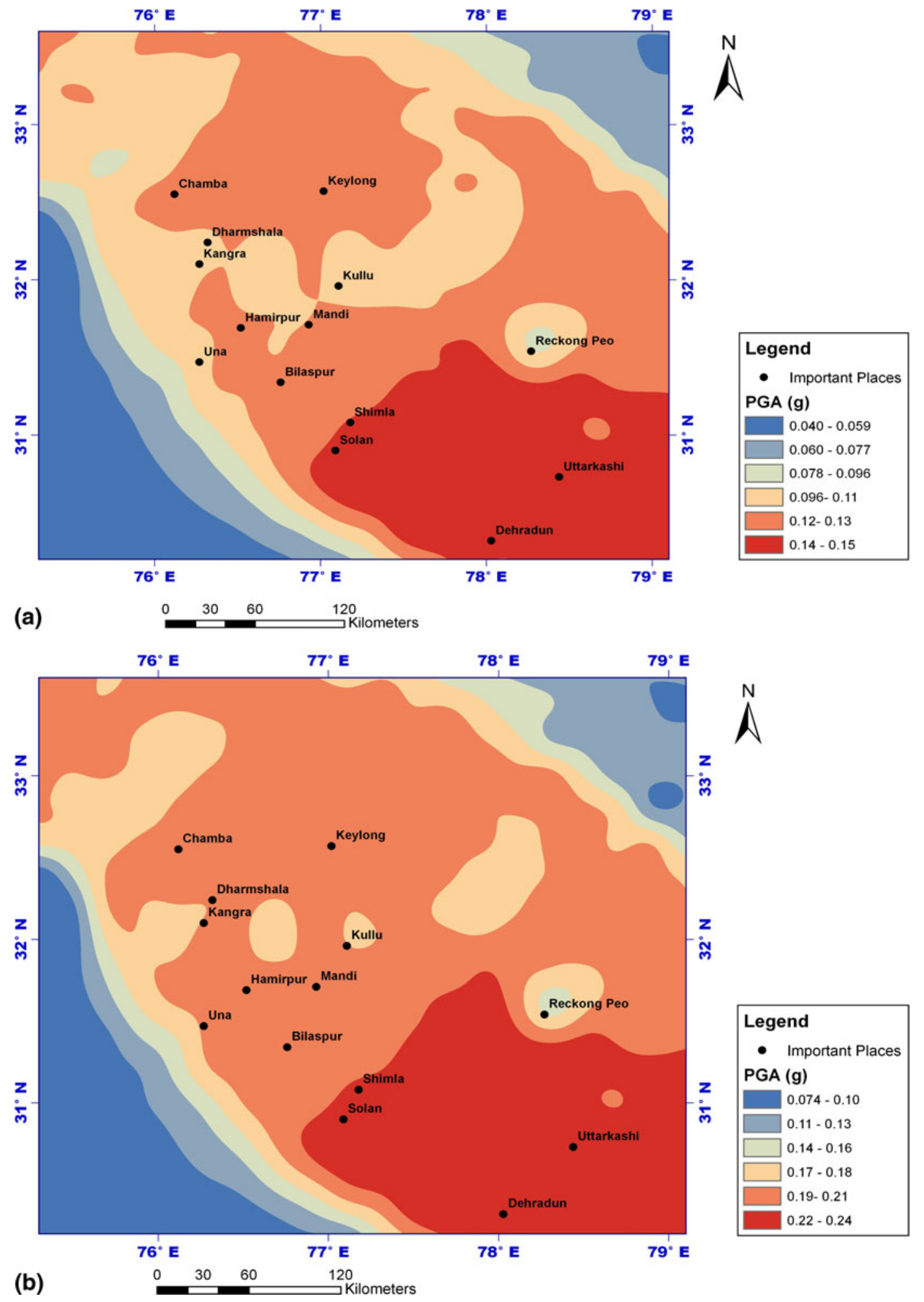

Figure 7. Peak ground acceleration for the return period (a) 475 years (Case I) and (b) 2500 years (Case I).

Based on the above discussion, it is observed that the estimated seismic hazard is on higher side in case constant $b$-value is taken, i.e., Case II. For return period of 100 years, the expected PGA is 0.082 and $0.18 \mathrm{~g}$ for varying and constant $b$-value, respectively. It is evident from table 5 , an increase of about $55 \%$ to $70 \%$ occurs in case of constant $b$-value over the varying $b$-value.

It is a fact that large number of parameters govern the estimation of seismic hazard and there can be some source of uncertainties. Probable source of uncertainties of this study may be the unknown 

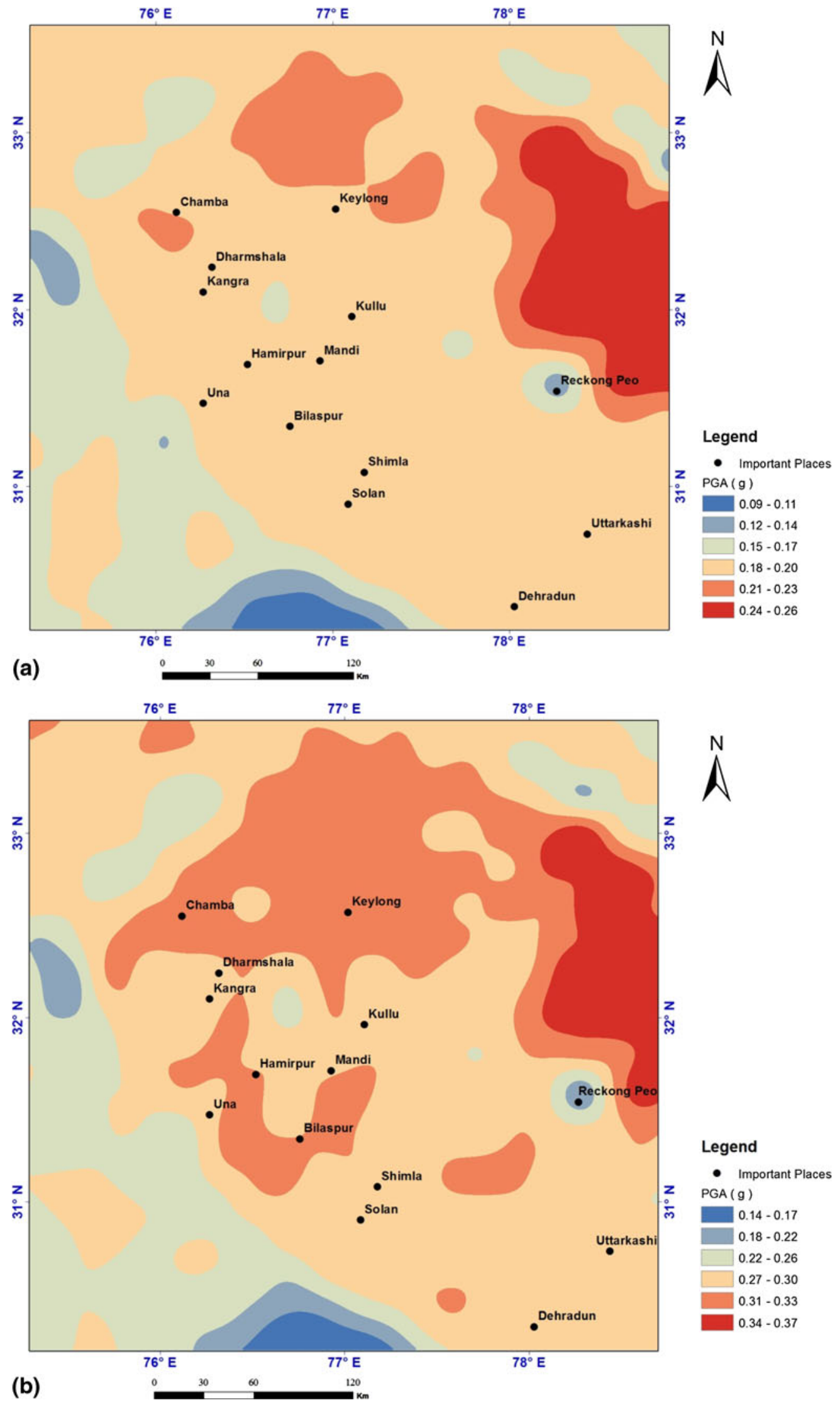

Figure 8. Peak ground acceleration for the return period (a) 475 years (Case II) and (b) 2500 years (Case II). 
Table 5. Increase in expected PGA (\%) considering varying and constant b-values.

\begin{tabular}{lccc}
\hline \multirow{2}{*}{$\begin{array}{l}\text { Probability of } \\
\text { exceedance } \\
\text { in 50 years }(\%)\end{array}$} & $\begin{array}{c}\text { Return period } \\
\text { (years) }\end{array}$ & $\begin{array}{c}\text { Expected PGA }(\mathrm{g}) \\
\text { (varying) }\end{array}$ & $\begin{array}{c}b \text {-value } \\
\text { (constant) }\end{array}$ \\
\hline 40 & 100 & 0.082 & 0.18 \\
20 & 225 & 0.11 & 0.21 \\
10 & 475 & 0.15 & 0.26 \\
5 & 1000 & 0.19 & 0.30 \\
2 & 2500 & 0.24 & 0.37 \\
\hline
\end{tabular}

Table 6. Comparison of the estimated PGA from present study with other studies.

\begin{tabular}{|c|c|c|c|c|c|}
\hline \multirow{2}{*}{$\begin{array}{l}\text { Research carried out } \\
\text { by author/agency }\end{array}$} & \multirow{2}{*}{$\begin{array}{l}\text { Type of } \\
\text { study }\end{array}$} & \multirow{2}{*}{$\begin{array}{l}\text { Return period } \\
\quad \text { (years) }\end{array}$} & \multicolumn{2}{|c|}{ Range of PGA (g) } & \multirow[b]{2}{*}{$b$-value } \\
\hline & & & Min. & Max. & \\
\hline Khattri et al. (1984) & PSHA & 475 & 0.40 & 0.70 & - \\
\hline Bhatia et al. (1999) & PSHA & 475 & 0.10 & 0.30 & - \\
\hline Parvez et al. (2003) & DSHA & - & 0.04 & 0.60 & - \\
\hline Mahajan et al. (2010) & PSHA & 475 & 0.02 & 0.50 & - \\
\hline NDMA, GOI (2011) & PSHA & 475 & 0.10 & 0.12 & - \\
\hline Present study & PSHA & 475 & $\left\{\begin{array}{l}0.08 \\
0.09\end{array}\right.$ & 0.15 & $b$-varying \\
\hline & & & 0.09 & 0.26 & $b$-constant \\
\hline
\end{tabular}

fault rupture process, three dimensional geometries of seismogenic zones, source parameters for large number of earthquakes and attenuation relations. The most important task is to identify and demarcate seismogenic source zones. For our study area the source zones were demarcated using information on geological structures, tectonic features and seismicity pattern. The area shows several clusters of seismicity related to tectonic features in some cases and forms a particular zone. Another important aspect in PSHA is the selection of proper attenuation model for the region. Although the regional attenuation model is preferred, it should be well constrained by the strong motion data in the magnitude-distance space. In the absence of appropriate regional attenuation model, attenuation models derived considering the worldwide strong motion data of shallow crustal earthquakes is adopted. The above mentioned uncertainties can be minimized with the availability of properly recorded earthquake data and detailed information on rupture processes based on refined earthquake data analysis.

Several authors have attempted to estimate PSHA for Indian subcontinent and for different parts of the country (e.g., Khattri et al. 1984; Bhatia et al. 1999). Some of these studies cover the state of HP. Based on the PSHA of India and adjacent areas, Khattri et al. (1984) estimated expected PGA at bed rock range from 0.4 to $0.7 \mathrm{~g}$ with $10 \%$ probability of exceedance in 50 years for the HP which falls in the Himalayan region. Bhatia et al. (1999) estimated expected PGA for the Himalayan region (including the state of $\mathrm{HP}$ ) between 0.10 and $0.30 \mathrm{~g}$ with $10 \%$ probability of exceedance in 50 years. These values were obtained under Global Seismic Hazard Assessment Programme (GSHAP). Parvez et al. (2003) conducted DSHA of India and adjoining region and observed wide variation in Design Ground Acceleration (DGA). For the Kangra region of HP, DGA range from 0.30 to $0.60 \mathrm{~g}$, whereas in the rest of the state estimated DGA ranges from 0.040 to $0.30 \mathrm{~g}$. This variation in DGA seems to be due to uncertainties in fault rupture parameters of historical earthquakes (e.g., Kangra earthquake) taken into computation of DGA. In a study based on PSHA carried out by Mahajan et al. (2010) for the north-western Himalaya and adjoining area, the estimated PGA in Kangra region varies from 0.020 to $0.50 \mathrm{~g}$ whereas for adjoining regions it is of the order of 0.20 to $0.50 \mathrm{~g}$ for $10 \%$ probability of exceedance in 50 years. Recently National Disaster Management Authority (NDMA 2011), Government of India presented various probabilistic seismic hazard maps showing the ground motion parameters for different return periods for the whole country. This study has brought out that in the state of HP, the estimated PGA ranges from 0.10 to $0.12 \mathrm{~g}$ for A-type soils (hard rock) for 475 years return period. 
Table 6 shows a comparison of expected PGA for the state obtained from different studies including the present study. The PGA obtained in the present study is by and large in agreement with that estimated by Bhatia et al. (1999) and NDMA (2011) for 10\% probability of exceedance in 50 years. However, in comparison to Khattri et al. (1984) and Mahajan et al. (2010), the results obtained are on the lower side.

\section{Conclusions}

For this study seismic hazard parameters in terms of PGA has been estimated considering: (i) estimated $b$-value for each seismogenic source zone, and (ii) constant $b$-value obtained considering entire earthquake catalog. The following broad conclusions could be drawn from the study.

- For all return periods, the estimated PGA considering constant $b$-value for all the source zones is on higher side as compared to those obtained using varying $b$-value for each source zones. For 475 years return period, in the region enclosed by state boundary, the PGA values vary from 0.096 to $0.15 \mathrm{~g}$ and 0.09 to $0.26 \mathrm{~g}$ considering varying $b$-value and constant $b$-value, respectively. However, considering constant $b$-value for most of the region in the state, the PGA varies from 0.09 to $0.26 \mathrm{~g}$.

- For 2500 years return period, the PGA varies between 0.17 to $0.24 \mathrm{~g}$ considering varying $b$-values and 0.14 to $0.37 \mathrm{~g}$ considering constant $b$-values.

- The ground motion distribution pattern, as evidenced by the contours, by and large remained same for different return periods in both the cases by considering varying $b$-values and a constant $b$-value.

- Higher PGA values are observed in the southeast region of the state including state capital Shimla considering varying $b$-values whereas in case of constant $b$-value the region situated around KFS shows higher PGA.

- The seismic hazard map obtained for HP with varying $b$-value for ten delineated seismic zones may be adopted as this method fulfils to greater extents the required philosophy of probabilistic seismic hazard assessment.

\section{Acknowledgements}

Earthquake data from India Meteorological Department, India, US Geological Survey, USA and International Seismological Centre, On-line Bulletin, United Kingdom catalogs have been used in this study and the authors remain grateful for this support.

\section{References}

Bhatia S C, Kumar R M and Gupta H K 1999 A probabilistic seismic hazard map of India and adjoining regions; Ann. Geofis. 42(6) 1153-1164.

BIS Code 18932002 Earthquake hazard zoning map of India; www.bis.org.in

Boore D M and Atkinson G M 2008 Ground-motion prediction equations for the average horizontal component of PGA, PGV, and 5\%-damped PSA at spectral periods between $0.01 \mathrm{~s}$ and $10.0 \mathrm{~s}$; Earthq. Spectra 24 99-138.

Chander R 1988 Interpretation of observed ground level changes due to the 1905 Kangra earthquake, Northwest Himalaya; Tectonophys. 149 289-298.

Cornell C A 1968 Engineering seismic risk analysis; Bull. Seismol. Soc. Am. 58 1583-1606.

Das R, Wason H R and Sharma M L 2012a Magnitude conversion to unified moment magnitude using orthogonal regression relation; J. Asian Earth Sci. 50(2) 44-51.

Das R, Wason H R and Sharma M L 2012b Temporal and spatial variations in the magnitude of completeness for homogenized moment magnitude catalog for Northeast India; J. Earth Syst. Sci. 121(1) 19-28.

Das R, Wason H R and Sharma M L 2013 General orthogonal regression relation between body and moment magnitudes; Seismol. Res. Lett. 84(2) 219-224.

Development of probabilistic seismic hazard map of India 2011 Technical Report, National Disaster Management Authority (NDMA), Government of India, New Delhi.

GSI 2000 Seismotectonic Atlas of India and its Environs; Geological Survey of India.

Gansser A 1977 The great Suture Zone between Himalaya and Tibet: A preliminary note; Sciences de la Terre: Himalayas CNRS 268 181-192.

Gardner J K and Knopoff L 1974 Is the sequence of earthquakes in southern California, with aftershocks removed, Poissonian? Bull. Seismol. Soc. Am. 64 1363-1367.

Gutenberg B and Richter C F 1944 Frequency of earthquakes in California; Bull. Seismol. Soc. Am. 34(4) 1985-1988.

Iyengar R N, Sharma D and Siddiqui J M 1999 Earthquake history of India in medieval times; Ind. J. Hist. Sci. 34(3) $181-237$.

Joshi G C and Sharma M L 2008 Uncertainties in the estimation of $\mathrm{M}_{\max }$; J. Earth Syst. Sci. 117 671-682.

Kijko A 2004 Estimation of the maximum earthquake magnitude, $\mathrm{M}_{\max }$; Pure Appl. Geophys. 161 1655-1681.

Kramer S L 2003 Geotechnical Earthquake Engineering, Prentice Hall International Series, Pearson Education, Delhi, Chapter 4.

Khattri K N, Rogers A M, Perkins D M and Algermissen S T 1984 A seismic hazard map of India and adjacent area; Tectonophys. 108 93-134.

Mahajan A K, Thakur V C, Sharma M L and Chauhan M 2010 Probabilistic seismic hazard map of NW Himalaya and its adjoining area, India; Nat. Hazards 53 443-457.

Middlemiss C S 1909 Preliminary account of the Kangra earthquake of 4th April 1905; Geol. Soc. India Memoir 32(4) 258-294.

Musson R 1999 Probabilistic seismic hazard maps for the North Balkan region; Ann. Geofis. 42(6) 1109-1124.

Oldham T 1883 A catalog of Indian earthquakes from the earliest times to the end of 1869 AD; Geol. Surv. India Memoir, XIX Part-3.

Ordaz M, Aguilar A and Arboleda J 2003 Crisis 2003: Program for computing seismic hazard, Ver. 3.01. 
Parvez I A, Vaccari F and Panza G F 2003 A deterministic seismic hazard map of India and adjacent areas; Geophys. J. Int. 155(2) 489-508.

Quittmeyer R C and Jacob K H 1979 Historical and modern seismicity of Pakistan, Afghanistan, north-western India and south-eastern Iran; Bull. Seismol. Soc. Am. 69 773-823.

Reiter L 1990 Earthquake hazard analysis: Issues and insights (Columbia, USA; Columbia University Press).

Ristau J 2009 Comparison of magnitude estimates for New Zealand earthquakes: Moment magnitude, local magnitude, and teleseismic body-wave magnitude; Bull. Seismol. Soc. Am. 99 1841-1852.

Srivastava H N, Verma M and Bansal B K 2010 Seismological constraints for the 1905 Kangra earthquake and associated hazard in northwest India; Curr. Sci. 99(11) 1549-1559.

Stepp J C 1972 Analysis of the completeness of the earthquake sample in the Puget Sound area and its effect on statistical estimates of earthquake hazard; Proc. Inter. Conf. Microzonation, Seattle Washington, USA 64 1189-1207.

Thingbaijam K K S, Nath S K, Yadav A, Raj A, Walling M Y and Mohanty W K 2008 Recent seismicity in northeast India and its adjoining region; J. Seismol. 12 107-123.

Valdiya K S 1980 Geology of Kumaun Lesser Himalaya; Wadia Institute of Himalayan Geology, Dehradun, pp. 290-291.

Wason H R, Das R and Sharma M L 2012 Magnitude conversion problem using General Orthogonal Regression; Geophys. J. Int. 190(2) 1091-1096.

Wiemer S and Wyss M 2001 ZMAP: A Tool for Analyses of Seismicity Patterns; A Cookbook, 57p.

Woessner J and Wiemer S 2005 Assessing the quality of earthquakes catalogs: Estimating the magnitude of completeness and its uncertainty; Bull. Seismol. Soc. Am. 95(2) 684-698. 